\title{
Program Jaminan Kesehatan Nasional dan Angka Kematian Ibu di Kota Bogor (Studi Fenomena dan Dampak Kesehatan)
}

\author{
Helfi Gustia ${ }^{1}$, Susilahati², Dwijo Susilo ${ }^{3}$ \\ Lembaga Penelitian dan Pengembangan Masyrakat Universitas Muhammadiyah Jakarta
}

\begin{abstract}
Abstrak
Telah terjadi perubahan besar terhadap sistem kesehatan nasional dengan adanya implementasi JKN. Perubahan tersebut terutama pada sub sistem pembiayaan dan upaya kesehatan. Sebelum ada program JKN ada beberapa program jaminan kesehatan kepada masyarakat yang dapat diakses oleh seluruh masyarakat tanpa terkecuali dan kini hanya dapat dinikmati oleh peserta JKN saja. Salah satu program yang dihapus sejak diberlakukannya JKN adalah program jaminan persalinan universal (Jampersal). Penelitian ini bertujuan mempelajari program JKN dan Angka Kematian Ibu. Penelitian ini telah dilaksanakan di Kota Bogor untuk mewakili karakteristik geografi yang berbeda, karena pada tahun 2015 dilakukan di Kabupaten Bogor. Rancangan penelitian yang digunakan adalah studi kuantitatif. Hasil penelitian menunjukkan angka kematian ibu melahirkan di Kota Bogor bukan hanya semata dipengaruhi oleh pembiayaan persalinan, tetapi juga oleh kesadaran masyarakat akan pentingnya pemenuhan upaya kesehatan yang terlihat dari jumlah kepesertaan JKN yang semakin meningkat. Disamping itu juga didukung antara lain oleh program EMAS yang didanai oleh APBD, opat sedayungan (kerjasama yang baik antara petugas kesehatan, kader, keluarga dan masyarakat).
\end{abstract}

Kata Kunci : AKI, implementasi, JKN

Korespondensi: Helfi Gustia, Lembaga Penelitian dan Pengembangan Masyrakat Universitas Muhammadiyah Jakarta. Jl KH Ahmad Dahlan Ciputat Cirendeu mobile 08129989896, e-mail: helfi_umj@yahoo.com 


\section{Pendahuluan}

Berdasarkan Survei Demografi dan Kesehatan Indonesia (SDKI) tahun 2012 angka kematian ibu (AKI) di Indonesia masih tinggi sebesar 359 per 100.000 kelahiran hidup. Target global MDGs (milinium Development Goals) kelima adalah menurunkan angka kematian ibu menjadi 102 per 100.000 penduduk kelahiran hidup pada tahun $2015 .{ }^{1}$ Mengacu pada kondisi tersebut diatas maka diperlukan sebuah program untuk mengatasi AKI yang masih memprihatinkan. Faktor faktor yang mempengaruhi kematian ibu diantaranya jenis pekerjaan, riwayat antenatal care, rujukan,Komplikasi kehamilan, riwayat penyakit, komplikasi kehamilan. ${ }^{2,3}$

Jaminan Kesehatan Nasional adalah program jaminan sosial yang menjamin biaya pemeliharaan kesehatan serta pemenuhan kebutuhan dasar kesehatan yang diselenggarakan nasional secara gotong royong wajib oleh seluruh penduduk Indonesia dengan membayar iuran berkala atau iuran yang dibiayai oleh pemerintah kepada badan penyelenggara jaminan sosial kesehatan nirlaba-BPJS Kesehatan yang bertujuan memberikan manfaat pemeliharaan kesehatan dan perlindungan akan pemenuhan kebutuhan dasar kesehatan. ${ }^{4}$ Telah terjadi perubahan besar terhadap sistem kesehatan nasional dengan adanya implementasi JKN. Perubahan tersebut terutama pada sub sistem pembiayaan dan upaya kesehatan. Sebelum ada program JKN ada beberapa program jaminan kesehatan kepada masyarakat yang dapat diakses oleh seluruh masyarakat tanpa terkecuali dan kini hanya dapat dinikmati oleh peserta JKN saja.Salah satu program yang dihapus sejak diberlakukannya JKN adalah program jaminan persalinan universal (Jampersal).Dengan adanya kebijakan JKN tentu saja berdampak pada upaya penurunan kematian ibu yang merupakan salah satu prioritas pembangunan kesehatan nasional.

Maka dari itu perlu melakukan evaluasi implementasi kebijakan JKN terhadap upaya peningkatan kesehatan ibu dan anak. Penelitian ini bertujuan melihat program JKN dankematian ibu sebagai sebuah fenomena dan melihat dampak bagi kesehatan ibu.Penelitian ini telah dilaksanakan di Kota Bogor untuk mewakili karakteristik geografi yang berbeda, karena pada tahun 2015 dilakukan di Kabupaten Bogor.Kabupaten Bogor mewakili daerah pedesaan (rural) dan Kota Bogor mewakili daerah perkotaan (urban).Hasil penelitian di Kabupaten Bogor pada tahun 2015 menunjukkan bahwa terjadi penurunan jumlah ibu yang melakukan persalinan dengan menggunakan pembiayaan JKN dibandingkan dengan pembiayaan Jampersal.

\section{Metode}

Rancangan penelitian yang digunakan analisis data kualitatif dengan melakukan analisis isi menggunakan matriks hasil wawancara. Hasil wawancara ini juga akan dikuatasi untuk memperdalam dan mendukung pembahasan hasil penelitian.

\section{Hasil dan Pembahasan}

Pada peride tahun 2015 - 2016 tidak terjadi penurunan angka kematian ibu.Banyak faktor yang memprngaruhi angka kematian ibu berdasarkan data yang diperoleh Dari Dinas Kesehatan Kota Bogor. 
Penerapan program JKN di Kota Bogor mengikuti peraturan yang berlaku, baik peraturan yang diterbitkan oleh Menteri Kesehatan, Dinas Kesehatan, dan Pemda, dan penerapan strateginya sesuai dengan protap yang telah ditentukan. Berdasarkan hasil wawancara dengan informan bahwa: Penerapan program dan strategi JKN sesuai aturan aturan yang berlaku dan sesuai protap yang telah ditentukan.

Menurut Informan penerapan program JKN di setiap Puskesmas tetap mengikuti aturan-aturan yang berlaku, baik yang ditetapkan oleh Menteri Kesehatan maupun peraturan-peraturan yang dibuat ditingkat Pemda dan Dinas Kesehatan.Prinsipnya adalah mengikuti aturan yang ada baik Permenkes, Perwali ataupun peraturan dari Dinas Kesehatan Kota. Untuk program JKN yang dikelola oleh pemerintah, tahap awal program ini ada tiga kebijakan, yaitu 1) Kementerian Dalam Negeri karena Kota Bogor di bawah Kementerian Dalam Negeri, 2) Kementerian Kesehatan karena Dinas Kesehatan di bawah Kementerian Kesehatan, dan 3) dari BPJS sendiri yang independen (bukan di bawah Kementerian Kesehatan). Dengan adanya tiga kebijakan ini perlu dilakukan sinkronisasi agar tidak terjadi satu dan lainnya saling berlawanan.

Jika dibandingkan program JKN dengan program Jampersal, menurut informan adalah Jampersal itu hanya dikelola oleh Kementerian Kesehatan, kemudian pembiayaannya juga jelas penganggaran dari APBN, beda dengan JKN karena JKN di kelola oleh BPJS sendiri, dan anggarannya didapat dari pembiayaan, ada yang pembiayaan mandiri dan ada yang subsidi (PBI). Untuk yang pembiayaan mandiri tidak masalah, tetapi bagaimanan dengan yang tidak mampu ini (PBI)?

Strategi program JKN di lingkungan kerja dilaksanakan sesuai protap yang telah ditentukan oleh JKN seperti rujukan - rujukan masalah kebidanan disesuaikan dengan kode kode diagnosa yang ditentukan oleh JKN, bila diagnosa tidak ada dalam aturan tersebut maka tidak dapat diberikan rujukan JKN".Di samping itu penerapan strategi program JKN adalah Kapitasi dan non kapitasi. Jika kapitasinya $100 \%$, maka untuk faskes adalah $70 \%, 20 \%$ medis, dan $10 \%$ antara lain untuk pelatihan. Sedangkan yang non kapitasi adalah yang dapat dirasakan langsung oleh masyarakat.Selain itu ada juga informan menyatakan PKM memberikan pelayanan kesehatan dasar yang bekerjasama dengan BPJS.Sistem pembiayaan penyedian, penyelenggaraan pelayanan kesehatan rujukan menggunakan sistem INAC BGs. PKM sebagai penyelenggara dituntut menyelesaikan 144 diagnosa penyakit, juga memberikan pelayanan preventif dan promotif'.

Berdasarkan hasil wawancara dengan informan upaya penurunan angka kematian ibu (AKI) dan angka kematian bayi (AKB) melalui implementasi program JKN dapat dilakukan dengan berbagai cara antara lain penguatan faskes tingkat pertama dan Dinas Kesehatan dalam pelayanan UKP dan UKM, sosialisasi yang aktif, pelatihan kader kesehatan dalam rangka pencegahan kesakitan dan kematian bayi dan balita. Diupayakan semua ibu hamil mempunyai jaminan kesehatan sejak bayi baru lahir sudah terproteksi apabila ada gangguan kesehatan. 
Di samping itu juga menyediakan alat kesehatan dan tenaga kesehatan yang cukup, mengharuskan ibu hamil memeriksakan kehamilannya di PKM dan segera dirujuk jika ditemukan penyulit dalam kehamilan.

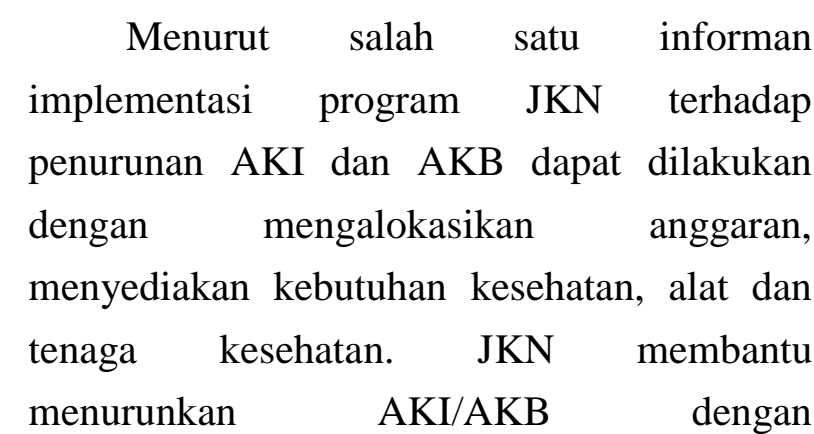
memberlakukan semua ibu hamil harus melakukan pemeriksaan kehamilannya di FKTP dan jika di temukan penyulit pada kehamilannya segera dirujuk ke RS. Program JKN hanya berlaku untuk peserta BPJS saja. Upaya lain dapat dilakukan dengan sosialisasi yang aktif mengenai resiko tinggi dengan memanfaatkan layanan singkat, pelatihan kader kesehatan dalam rangka pencegahan kesakitan dan kematian bayi dan balita. Selain itu semua ibu hamil mempunyai jaminan kesehatan sejak bayi baru lahir sudah terproteksi apabila ada gangguan kesehatan.

Ditambahkan oleh informan lain biaya untuk anggota yang PBI untuk bantuan iyuran ibu hamil digratiskan, selain itu pada program JKN ada dana kapitasi yang masuk ke Puskesmas sebesar 30\% di Kota Bogor, dana ini dipakai untuk operasional Puskesmas. Sebesar $10 \%$ digunakan untuk promosi kesehatan dan $20 \%$ promosi misalkan untuk Posyandu untuk itu secara tidak langsung mungkin untuk upaya penurunan angka kematian dicegah dengan baik. Program kelas ibu misalnya untuk penyuluhan ibu yang melahirkan juga bisa dari JKN, untuk sosialisasi pelatihan disiapkan dari 30\% untuk operasional Puskesmas dapat dari alokasi JKN. Pendapat ini ditambahkan oleh informan lain yang mengemukakan implementasi program JKN terhadap penurunan AKI dan AKB cukup membantu karena memperoleh sistem rujukan, setiap rumah sakit harus menerima JKN. JKN juga dapat disesuaikan dengan kelas rawat sesuai pendaftaran peserta.Selain itu semua ibu hamil mempunyai jaminan kesehatan sejak bayi baru lahir sudah terproteksi apabila ada gangguan kesehatan.

Namun ada informan yang mengemukakan implementasi program JKN dalam penurunan AKI dan AKB melalui pemanfaatan kartu lebih sulit dengan JKN, karena untuk JKN sekarang itu pemanfaatannya melalui wilayah, karena aturan dari BPJS per wilayah misalkan mendaftar BPJS di wilayah $X$, maka berobatnya juga di wilayah $\mathrm{X}$ kecuali dalam persalinan, tidak memandang lokasi BPJSnya aktif kemudian dia punya KTP dan KK bisa dipergunakan kartu JKN baik yang mandiri ataupun bantuan dari pemerintah.

Sedangkan implementasi program Jampersal dalam usaha penurunan AKI dan AKB menurut informan dari hasil wawancara adalah melalui Jampersal yang berlaku untuk meringankan biaya persalinan, menyamakan orang kaya dan tidak mampu. Sedangkan program jampersal mendekatkan akses layanan untuk seluruh ibu hamil, bersalin, nifas, dan bayi baru lahir. Selain itu mendekatkan akses layanan untuk seluruh ibu hamil, bersalin, nifas, dan bayi baru lahir, serta siapa pun yang hamil dan membawa KTP dan Kartu domisili dan tidak memandang domisili 
harus satu tempat tapi se Indonesia akan berlaku.

Dalam upaya penurunan AKI dan AKB Pemda juga berperan.Hal ini disampaikan oleh informan untuk program JKN ada kebijakan tertulis dan tidak tertulis. Program-program yang diandalkan dari Pemda untuk Dinas Kesehatan dalam rangka menurunkan AKI dan AKB antara lain pelatihan-pelatihan kader dari Dinas Kesehatan, anggaran dari Pemda dan sejak Maret 2016 ada program "opat sauyunan" (empat orang yang mendampingi ibu hamil). Program Emas untuk enam Puskesmas (satu per Kecematan) terutama Poned yang didanai dari APBD. Program Emas diadopsi dari program yang didanai USAID tahun 2014 di beberapa Provinsi termasuk Jawa Barat ada beberapa kabupaten/kota. Ketika wawancara berlangsung pelatihan program Emas Kota Bogor masih berjalan, dimana Puskesmas peserta dilatih oleh Puskesmas Kabupaten Bogor dan satu RSUD dilatih oleh RSUD Kabupaten Bogor.

Perubahan angka kematian ibu tidak semata mata dikarenakan oleh masalah penganggaran melainkan banyak faktor lainnya yang harus diperhatikan seperti jenis pekerjaan, riwayat antenatal care, rujukan, Komplikasi kehamilan, riwayat penyakit, komplikasi kehamilan. Program JKN yang berjalan sudah cukup baik namun perlu
Untuk Jampersal dukungan yang diberikan adalah memperkuat manajemen pengelolaan dari tingkat kota, membaut MoU antar Dinkes dan BPJS, sosialisasi dan monev.

Hasil wawancara dengan informan diperoleh keterangan bahwa ibu hamil yang memanfaatkan program JKN lebih rendah dari pada yang ikut program Jampersal. Hal ini sesuai dengan pendapat informan bahwa kalau jampersal itu banyak yang menggunakan kalau JKN itu yang ngak punya jampersal ibu hamil yang memanfaatkan program JKN kurang lebih $90 \%$ baik mandiri maupun subsidi, dan ibu hamil yang memanfaatkan program Jampersal dapat diberikan keseluruh ibu hamil tanpa memandang status dan tidak usah mendapat cukup KTP, KK, dan buku KIA.

Jumlah ibu hamil yang memanfaatkan program JKN tahun 2014 adalah 343 orang dan tahun 2015 sebanyak 343 orang, sedangkan yang ikut program Jampersal adalah 327 orang.

\section{Kesimpulan dan saran}

ditingkatkan lagi terutama pada penggunaan alokasi dana preventif promotive guna menekan angka kematian ibu. Seyogyanya program preventif promotive tersebut bukan hanya diintervensi mulai dari ibu hamil namun dilakukan dengan pendekatan sepanjang daur hidup manusia (mulai remaja).

\section{Daftar Pustaka}

1. Pusat Data dan Informasi Kemenkes RI. Situasi kesehatan ibu. Kemenkes. 2014

2. Sumarni. Faktor faktor yang mempengaruhi kematian ibu di 
Kabupaten Banyumas Jawa Tengah Periode Tahun 2009-2011. Bidan Prada: Jurnal Ilmiah Kebidanan, Vol. 5 No. 1 Edisi Juni 2014, hlm. 52-62

3. Nurul A. Faktor risiko kematian ibu. Jurnal Kesehatan Masyarakat Nasional Vol. 7, No. 10, Mei 2013
4. Asih EP. Paham JKN Jaminan Kesehatan Nasional. Friedrich-EbertStiftung Kantor Perwakilan Indonesia Dewan Jaminan Sosial Nasional (DJSN). September 2014 